\title{
Sidestream Movie as Media in Generating High Order of Thinking Skills
}

\author{
R Nufiarni ${ }^{1}$, S V Eka ${ }^{2}$, M A Nurmansyah ${ }^{3}$, F N Setiawan ${ }^{4}$ \\ ${ }^{1,2,3,4}$ Faculty of Cultural Studies Universitas Brawijaya, Jl. Veteran Malang, Indonesia
}

\{1nufiarni_rizki@ub.ac.id\}

\begin{abstract}
In the industry of Indonesian movies, the spotlight is mainly on mainstream movies, leaving sidestream movies underlit. Sidestream movies are less popular, yet they provide various themes and creativity more than the mainstream. Sidestream movies also often brought back prior themes from the mainstreams, meaning that they are both parallel. The less popularity of the sidestream movies is mainly affected by unbalanced movies' distribution line in Indonesia, which benefits only the mainstreams. Albeit deprived on the distribution, sidestream movies correspond the mainstream, in this era of industry 4.0, through their themes and discourses. This study aims to investigate two sidestream movies entitled Jumprit Singit and Nunggu Teka as the primary data. The result shows that the discourses of the two movies still rely on the conformity of norms and manner of Indonesian people. This idea is built through the movies' narrative discourses, showing a smaller dimension if they are compared with mainstream movies. Sidestream movies with drama genre show more conservatism and positivism whereas movies with comedy genre deliver more satire. Eventually, the relation between the discourses of mainstream and sidestream films are not always constructed in an oppositional relation as shown by this study.
\end{abstract}

Keywords: Sidestream Movie, Media, Discourse, Narrative Discourse

\section{INTRODUCTION}

Sidestream movies have begun to gain viewer's attention in Indonesia. This phenomenon is likely to happen because they presented various themes, compared to the mainstream movies. The themes range from domestic issues to more significant issues such as politics, nationality, etc. These issues are presented in such a way so that it may trigger the viewer's awareness. While the mainstream movies try to meet the demand of the viewers, sidestream movies are usually made to show the directors (or the producers) point of view.

Based on the research that we have conducted, sidestream movies does not necessarily to be in a different dimension from the mainstream movies. Both kinds of movie can have the same theme and idea but are pictured in a very different perspective. The two sidestream movies that we use in this research are entitled Jumprit Singit and Nunggu Teka. Both movies were created by a local director/producer. Both movies have achieved an international award. Jumprit Singit (2012) is one of the ten Indonesian short movies which becomes the nominee in 
Europe On Screen (EOS) in 2012[1]; while Nunggu Teka (2016) is the winner of Festival Sinema Australia Indonesia (FSAI) competition in 2017 which was being viewed in Melbourne International Film Festival (MIFF) from August 9-12, 2017 [2].

Unlike the mainstream movies which are distributed through the chain of theaters around the country, the sidestream movies are being distributed through online media channels. This line of distribution becomes an effective way of promoting movies to the viewers. Using this distribution line, sidestream film has its place in the Indonesian market.

\section{RESEARCH METHOD}

This research is a qualitative descriptive research, where the primary data is taken from the sidestream movies and the secondary data is taken from interview with the director of the movies, other written reports and articles related to the theme of the movies. The primary data is taken from scenes and dialogues from the sidestream movies.

The analysis is conducted by examining the narrative from the movie using Seymour Chatman (1978)[3] narrative structure. The narrative is obtained by examining the story through events and existents. The visual narrative is taken from the cinematography aspects. The next step in the analysis is interpreting the discourse of the movie and relate it to the High Order Thinking Skills.

\section{RESULT AND DISCUSSION}

As stated previously, sidestream movies have a wide range of theme which is presented from a certain point of view. This research is conducted to observe two sidestream movies with different themes created by Mahesa Desaga, a local director/producer from Malang. The first movie entitled Jumprit Singit captured a moment in the everyday neighborhood, where a thief stealing some clothes collides with a boy looking for a way to play with his friends. The second movie entitled Nunggu Teka presented a mother who is waiting for her only son to come home during the Idul Fitri holiday. These two movies can be used as a media in generating high order of thinking skills through the discourse presented in it.

\subsection{Jumprit Singit Narrative and Discourse}

This movie is made with only two main characters, a thief and a boy. The thief is described as a young man dressed in a shirt, jeans, and a dull jacket. He is tall, skinny, and dark-skinned with a mustache and short beard. The boy is pictured as a 10-year-old boy wearing a t-shirt with a logo of the local football club and signatures of the players and uniform pants. He is wearing sandals. The boy is also skinny and dark-skinned. From the two characters, it can be seen that they both belong to mid-low class society.

The social background of the characters is also shown in the location used in the movie. There are some locations which become the central point of the interaction between the characters in this movie. The first location is the field where the children in the neighborhood interact and play some games together. At the opening of the movie, some groups of children are playing together. They look so happy and lively running around the field. Aside from being a playground for children in the neighborhood, the field also serves as a place for political campaign. In the picture, it can be seen that the field is empty, but the wall 
surrounding the field is used as a media for the candidates of the chief of the village to post their campaign posters.

The second location in this movie is the PlayStation rental-house where many children in their uniform pants watch their friends playing the game. The children look very serious in watching the game, and the situation is different from the children playing in the field. The physical activity that can be seen in the first location cannot be seen in the second location where children only sit and stare at the monitor. This is a real picture of what happened in society nowadays. Children playing together in the field are rarely found. Instead, children usually play console game after school. In the low mid society, these children will go to a rental-house together and spend hours playing games not doing physical activities.

Another location used in the movie is a post where men usually guard their village during night time. The security post is used as a place for socializing for people in the neighborhood. Here, men are playing chess, card games, and talk about various things. Their activities are somewhat similar to the young boys' activity in the rental house. They group and watch some of them playing games.

The last location which is used in this movie is the alleys in the neighborhood. These alleys are connected and there are some alleys so small that people can hide from others. In this little alley, the two main characters of the movie met and made interaction. The thief hiding from the people chasing him meets the boy who plays alone since he cannot attract his friends to play with him. The boy, who see that the thief attract many people, asks the thief what he is doing.

\begin{tabular}{|c|c|}
\hline Boy & : Mas sampeyan lapo? \\
\hline Thief & Sst... \\
\hline Boy & : Lapo sampeyan mas? \\
\hline Thief & : Singitan \\
\hline Boy & Lha lapo kok singitan? \\
\hline Thief & : Dulinan jumprit singit \\
\hline Boy & Wis gede kok dulinan jumprit singit? \\
\hline Thief & : Jaman saiki, yo dulinan jumprit singit ngene iki. \\
\hline Boy & : Iku opo mas? \\
\hline Thief & Yo syarate iki nek ate dulinan jumprit singit \\
\hline Boy & : Sir, what are you doing? \\
\hline Thief & : Sst... \\
\hline Boy & : What are you doing, Sir? \\
\hline Thief & : I'm hiding. \\
\hline Boy & : Why are you hiding? \\
\hline Thief & : I'm playing hide and seek. \\
\hline Boy & : What makes grown man like you play hide and seek? \\
\hline Thief & : Nowadays, everybody plays hide and seek like this. \\
\hline Boy & What is that, Sir? \\
\hline Thief & : This is the rule for playing hide and seek, nowadays. \\
\hline
\end{tabular}

(minute: 00:04:50 - 00:05:34)

The dialog shows that the thief is lying to the boy about what he is doing. He said that he is playing hide and seek, and the boy believes what he said. Based on this conversation, the naïve boy tries to copy what the thief is doing by taking the PlayStation controller from his friends. This action leads to the chasing of the boy by the other children who feel disturbed. 
Jumprit Singit is a movie which presents critics for society. It is delivered with irony which is presented through the locations, the actions and the dialogues between the characters in the movie. The location used in the movie is not explicitly mentioned; this shows that the events might happen everywhere regardless of the city, or the country. The characters in this movie are also nameless, to show that it might happen to anyone. The action and the dialog is a portrait which might occur in any society, where people usually take information for granted. The boy who gets information from the thief thinks that the thief is honest, thus leads him to a crime, which he does not realize.

In the movie, the characters are chosen to meet the actual condition in society. The children are depicted as children of middle-class community in Indonesia, the class with the most population in Indonesia.

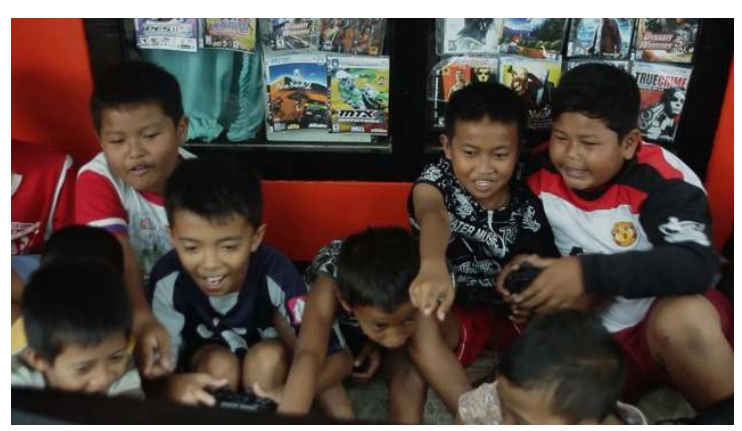

Figure 1. Children are playing PlayStation.

In figure 1, the children are playing games at somebody's porch. It is a common situation in the mid-low class area called kampong. Because of the limited living space and the character of kampong people, they do not have a specific boundary on privacy. They usually blur the limit of personal and public space, by practicing things usually done inside the house, at the outside of the home (the porch).

Not only the main character (the boy) and his friends, the other character, the thief is depicted as also from mid-low class Indonesia. He wears worn out clothes and sandal similar to the boy. It the figure below, the two are shown talking, even though they do not know each other.

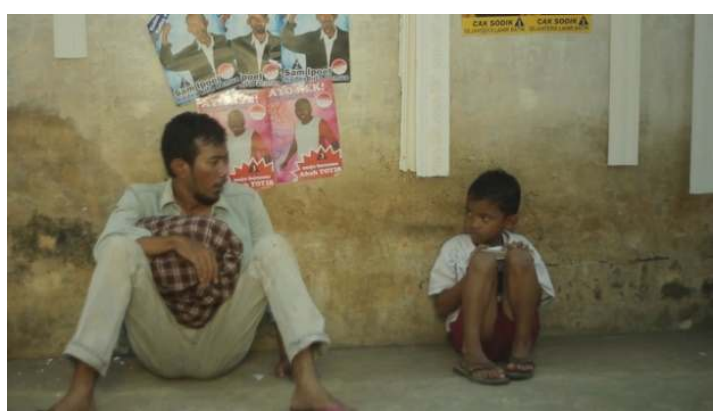

Figure 2. The thief and the boy. 
It is natural in Indonesia to talk to a stranger, typically in the kampong, and it is an Indonesian custom too, to respect elders. In the scene, because the thief is much older than the boy, the boy respects and believes him; then follow him to 'play' hide and seek.

After the boy steals the game console, immediately following the children, all people in the neighborhood come together to chase the boy. The strong connection between people in the mid-low class Indonesia creates this kind of system. Mid-low class Indonesia has a unique system of security, performed traditionally, it is under the social system as a way of keeping the people secure.

All the scenes in the movie have a common property: the brochure of the campaign. This situation is also an ordinary thing found in mid-low class areas. The mid-low class people do not have sufficient access to education and funding, which then make them cannot propose a representative from their area. They, on the contrary, usually become the object of the campaign from parties outside the area, making them as the basis to political commodity.

The choice of the characters and the setting and the properties in this movie create the discourse of ordinariness of life in a kampong in Indonesia. The movie brings the idea that it is how ordinary life happens in Indonesia. In the movie, several statements are being criticized; (1) honesty, (2) strong cultural surveillance, (3) sense of respect to elders, (4) connection between people from the same class, and (5) the use of mid-class society as a political commodity. Those are the ordinary things in mid-class social life, and through funny way, the movie criticizes them.

\subsection{Nunggu Teka Narrative and Discourse}

The second movie in this research is entitled Nunggu Teka. There is only one character that can be seen in this movie, a mother who is waiting for his son to come home. The cast is pictured as a woman in her 50s, with a tall and skinny figure, wrinkles in her face and grey hair as seen in figure 3 :
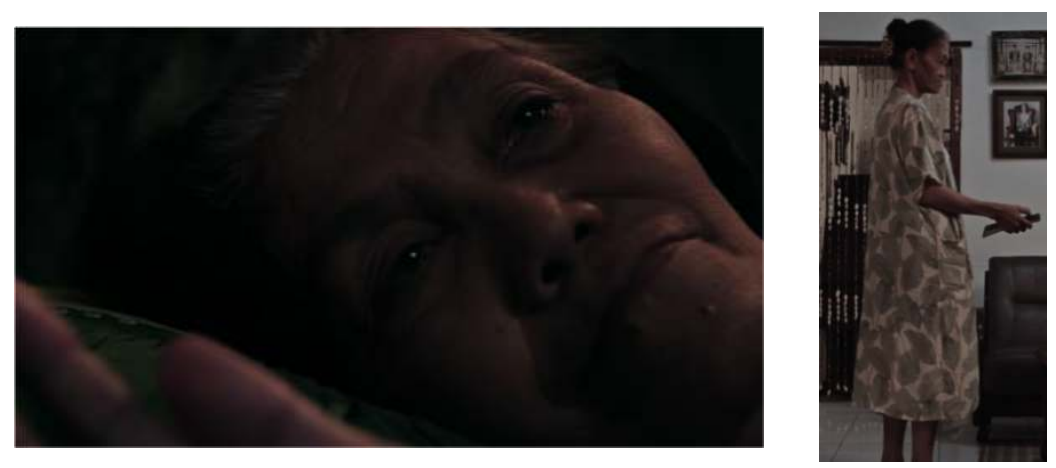

Figure3. Bik Nah

The character, Bik Nah, lives alone in her house. He has one son, whose photos are on the wall and the desk. In her room, Bik Nah keeps a photo of herself together with her son, her daughter in law and her grandson.

Bik Nah is an old woman who lives an ordinary life, shown by the simple meal she cooks and the old furniture in the house she lives. She is also a polite woman who can be seen from her interaction with her neighbor. The language she uses during her interaction with her neighbor shows that she highly respects her neighbor. Bik Nah is also a patient woman, in 
terms of waiting for her son to come home, and in terms of her interaction with other neighbours. She is also a loving mother, who prepares her only son's favorite foods to welcome her son, even though he has not given her the exact date of his arrival.

Unlike the previous movie, this movie only uses one location, Bik Nah house. From all the scenes, there are only several rooms depicted, which are the bedroom, the living room, the dining room, and the kitchen. Here, the location is used to strengthen the idea of 'coming home,' a place where a mother waits.

This movie pictures the situation taken place during the Idul Fitri celebration when people come home for the celebration of Idul Fitri every year. The ritual is common in a society where people usually work outside the town. They come back and celebrate Idul Fitri with their family. In Indonesia, Idul Fitri is a moment of joy where people gather to celebrate it with family. But it is not only about gathering with family, but it also means the celebration of the new self. Idul Fitri in Islam is a final day after 30 days of fasting to be closer to God, to clean the self from desire, internal sins and external sins (sins developed from interaction with other people). On Idul Fitri day, people gather with family to not only celebrate the coming of the new self but also to ask for forgiveness from other people, especially parents. Thus, for people having the parents outside the town, they have to come home to celebrate the day and to ask forgiveness from their parents.

This annual habit shapes culture in every country with the moslem population. Including in Indonesia, having the most significant moslem population, this culture shoves people to move almost in all parts of the region. Coming home to parent's house at Idul Fitri becomes not only a habit but also a social regulation called as mudik. Mudik is accepted in Indonesia not only as moslem's practice, but it has developed to be a custom, a norm that everyone in Indonesia take and exercises it directly or not.

As an important day for Moslems in Indonesia, Bik Nah in the movie is living alone at her home patiently waiting for her son to come home on Idul Fitri. Since the beginning, Bik Nah is hopefully waiting for her son, the hope and joy is shown through the enthusiasm when she prepared her son's favorite dish, and snacks; but eventually, he never comes. The day should be a day of the joyful moment, which is waited hopefully, but in this movie, it turns out to be a fruitless moment. From the movie is the word hope and joy which becomes an irony in the movie. This movie tried to picture a mother who is happily, sincerely and patiently waiting for her son to come home.

\subsection{High Order Thinking Skill Through Movie}

Understanding sidestream movies can be tools in learning values and people, to learn how people behave and how their behavior is reasoned by ideas. To be able to understand this, people need high order thinking skills. Wegerif states that "'Thinking skills' and related terms are used to indicate a desire to teach processes of thinking and learning that can be applied in a wide range of real-life contexts"[3]. For this reason, thinking skills are always connected to real-life context, people behavior, their culture, and background knowledge. Not only those aspects, Wegerif continues that it also influenced by strategies, habits, attitudes, emotions, motivations, character or self-identity and community; because thinking is an individual and reciprocal social action.

Based on Blooms Taxonomy, the thinking skill has then grown into the higher order thinking skill (HOTS). Brookhart [4] states that HOTS is an ability to think of three aspects: (1) transfer, (2) critical thinking, and (3) problem-solving. The transfer is the ability to remember and recall the idea/ knowledge. Critical thinking is the ability to think critically, 
whereas problem-solving is the ability to relate the experience to the problem and to be able to solve the problem accordingly [5].

As the development of technology has improved, the learning activity also developed based on the medium [6]. Prior medium in the use of technology, computers and motion pictures have played a significant role up to nowadays [7]. But alongside the use of those, the film has entered and attended the line rapidly. From the wide range of films, the sidestream films can deliver more values than the mainstreams, because mainstream films are made more to meet the demand of the capital industry [8].

\section{CONCLUSIONS}

Teaching and real-life learning values are some things that are not easy to do. To be able to achieve this, people have to have a clear picture or the context on the object value. The film, in thinking skill, can be an optimum medium or mind-tool. The character and the scenes provide a clear image of the value, and the setting and the cinematography provide a context for the viewers to learn the value. The real-life illustration in the film is a perfect tool for the mind to relate the value to the personal experience easily.

\section{REFERENCES}

[1] https://entertainment.kompas.com/read/2012/11/21/06203211/10.Film.Pendek.Indonesia. Bersaing.di.Festival.Film.Eropa.)

[2] https://seleb.tempo.co/read/898822/nunggu-teka-karya-mahesa-desaga-tampil-difestival-film-melbourne

[3] Wegerif, Rupert. 2006. Literature Review in Thinking Skills, Technology and Learning. UK: Futurelab

[4] Brookhart S.2010.How to asses Higher-order thinking skill in your classroom.Virginia. $A S C D$

[5] M. Reza Jalilvand and N. Samiei, "The effect of electronic word of mouth on brand image and purchase intention," Mark. Intell. Plan., vol. 30, no. 4, pp. 460-476, Jun. 2012.

[6] K. Z. K. Zhang, C. M. K. Cheung, and M. K. O. Lee, "Examining the moderating effect of inconsistent reviews and its gender differences on consumers' online shopping decision," Int. J. Inf. Manage., vol. 34, no. 2, pp. 89-98, Apr. 2014.

[7] M. R. Ward and M. J. Lee, "Internet shopping, consumer search and product branding," J. Prod. Brand Manag., vol. 9, no. 1, pp. 6-20, Feb. 2000.

[8] Baymard Institute, "40 Cart Abandonment Rate Statistics," Baymard Institute, 2017. [Online]. Available: https://baymard.com/lists/cart-abandonment-rate. 